\title{
Patterns of wildlife use by the local communities from Jorgo-Wato Protected Forest, Western Ethiopia
}

\author{
Mosissa Erena ${ }^{1}$ and Taye Dega ${ }^{1}$ \\ ${ }^{1}$ Wollega University
}

September 8, 2020

\begin{abstract}
This study explored patterns of wildlife use by the local communities around Jorgo-Wato Protected Forest to understand its impacts on the future conservation of the forest. One hundred sixty-five respondents from five peasant associations found with a radius of $3 \mathrm{~km}$ from the forest were interviewed about patterns of wildlife use by the local communities. Also, a direct field survey using a transect line was carried out to document destructive resource use patterns. The study revealed that agricultural products $(94.72 \%)$, livestock and their products $(84.48 \%)$, and poultry $(51.48 \%)$ were the major sources of livelihood incomes for the local communities. A significant positive $(\mathrm{r}=0.900)$ relationship was recorded between the mean number of livestock and the mean annual income, and between mean land owned per household and mean annual income per household $(\mathrm{r}=0.930)$, which could be attributed to their contribution to generate income through diverse ways. The utilization of alternative energy has a positive impact on the future conservation of the forest. On the other hand, the study showed a significant negative relationship $(\mathrm{r}=-0.971)$ between fuel wood consumption and distance of households' residences from the forest which reveals the impacts of distance on fuel wood collection and transportation for use. Though timber, beehive preparation, construction materials, and commercial domestic tools were reported as the main reasons for resource extraction. Fuel wood and charcoal were not used for commercial purposes in the area. Livestock grazing, debarking of trees, selective logging over the coffee plantation, girdling trees, poaching, and cutting trees for timber were identified as destructive resource use patterns in JorgoWato Protected Forest. Hence, wildlife laws and conservation guidelines should be implemented to mitigate destructive resource use patterns to safeguard Jorgo-Wato Protected Forest and its wildlife resources in the future.
\end{abstract}

\section{Hosted file}

Manuscript.docx available at https://authorea.com/users/357094/articles/479823-patterns-ofwildlife-use-by-the-local-communities-from-jorgo-wato-protected-forest-western-ethiopia 